\title{
Increasing Knowledge of HIV/AIDS in Adolescents using Video-Blogging
}

\author{
Intan Manisha Natalia', Sondang Ratnauli Sianturi', Wilhelmus Hary Susilo² \\ 1 Sekolah Tinggi Ilmu Kesehatan Sint Carolus \\ 2 Universitas Persada Indonesia YAI
}

\section{Article Info}

Article History:
Submitted: Sept $22^{\text {nd }}, 2020$
Accepted: Jan $20^{\text {th }}, 2021$
Published: Feb $13^{\text {th }}, 2021$
Keywords:
Health Promotion;
HIV/AIDS; Knowledge; VLOG

\section{PENDAHULUAN}

HIV/AIDS merupakan virus yang menyerang sistem kekebalan tubuh manusia, sehingga tubuh menjadi lemah dalam melawan infeksi [1]. Masalah HIV/AIDS ini menjadi masalah global yang tercantum dalam Sustainable Development Goals (SDGs). SDGs memiliki target pada tahun 2030 yang disebut Three Zero: tidak ada lagi penularan infeksi baru HIV, tidak ada lagi kematian akibat AIDS, dan tidak ada lagi stigma dan diskriminasi pada orang dengan HIV/AIDS (ODHA) [2]. WHO

Corresponding author:

Sondang Ratnauli Sianturi

sondangrsianturi@gmail.com

Media Keperawatan Indonesia, Vol 4 No 1, February 2021

e-ISSN: 2615-1669

ISSN: 2722-2802

DOI: $\underline{10.26714 / \mathrm{mki} .4 .1 .2021 .22-28}$ menyatakan bahwa jumlah penderita HIV pada tahun 2018 di dunia yaitu 37,9 juta jiwa, dengan urutan enam terbesar ditempati oleh Afrika sebanyak 25,7 juta jiwa, Asia Tenggara 3,8 juta jiwa, Amerika 3,5 juta jiwa, Eropa 2,5 juta jiwa, Pasifik Barat 1,9 juta jiwa dan Mediterania Timur 400 ribu jiwa. Berdasarkan kelompok usia < 15 tahun terdapat 1,7 juta jiwa, dan kelompok usia dewasa 36,2 juta jiwa. Jumlah penderita yang baru terinfeksi HIV di dunia tahun 2018 berjumlah 1,7 juta jiwa [3]. 
Data laporan perkembangan HIV/AIDS dan Infeksi Menular Seksual (IMS) Triwulan II sampai dengan bulan juni 2018 di Indonesia didapatkan data bahwa jumlah penderita HIV adalah 21.336 jiwa, sedangkan penderita AIDS berjumlah 6.162 jiwa. Berdasarkan kategori umur penderita paling banyak berusia 25-49 tahun dan 2024 tahun yaitu 86,2\%. Di DKI Jakarta jumlah penderita HIV tahun 2018 adalah 3.118 jiwa, sedangkan jumlah penderita AIDS adalah 398 jiwa. Berdasarkan kategori usia jumlah kematian akibat AIDS di Indonesia, dari tahun 2017 sampai 2018 mengalami penurunan yaitu usia 20-29 dari 232 menjadi 115 jiwa, sedangkan untuk usia 1419 mengalami kenaikan yaitu kategori remaja dari 7 menjadi 16 jiwa [4].

Penyebaran HIV/AIDS sudah tidak didominasi dengan pemakaian jarum suntik narkoba, melainkan perilaku seks bebas dikalangan usia produktif. Perilaku seks bebas membuat banyak orang terjangkit penyakit HIV/AIDS dengan melakukan seks secara berganti-ganti [5]. Kondisi ini bisa terjadi karena kurangnya pengetahuan dikalangan remaja sehingga rentan melakukan perilaku beresiko terhadap masalah kesehatan [3]. Hasil penelitian [6] menyatakan rendahnya pendidikan pada kalangan remaja terutama pada remaja lakilaki akan mendukung meningkatkan angka HIV-AIDS karena terbuka peluang bagi kaum remaja untuk terlibat hubungan sex. Hasil survey menyatakan remaja merasa lebih nyaman ketika menceritakan tentang pendidikan seksual kepada teman sebaya (31\%) dibandingkan bicara kepada orang tua (24\%). Untuk mengurangi perilaku beresiko pada remaja salah satunya yaitu dengan memastikan $90 \%$ remaja muda mempunyai keahlian, pengetahuan dan kapasitas untuk melindungi diri sendiri dari HIV [3].

Berbagai upaya pemerintah telah dilakukan dalam menangani masalah kesehatan HIV/AIDS pada remaja seperti halnya menggalakkan kampanye informasi pencegahan HIV/AIDS dan penyakit menular di sekolah,kampus, dan lembaga pendidikan lain [7]. Upaya yang dilakukan pemerintah ini dirasakan kurang efektif karena metode dan media penyampaian yang kurang menarik dikalangan remaja milenial. Remaja milenial lebih tertarik dengan media audio visual dan gambar digital karena saat ini remaja milenial sudah memasuki gaya hidup baru yang tidak bisa terlepaskan dengan perangkat elektronik [8]. Hal ini dikuatkan oleh penelitian lain setelah dilakukan promosi kesehatan melalui media audio visual dan metode ceramah terhadap tingkat pengetahuan, diperoleh perbandingan yakni pengetahuan menggunakan media audio visual $p$ value 0,006 sedangkan media ceramah $p$ value 0,002 yang menyatakan bahwa media audio visual lebih efektif dibandingkan media ceramah [9].

Media yang di gunakan anak remaja saat ini yaitu Youtube, karena di youtube tersedia hiburan dan informasi yang diinginkan. Salah satu konten video yang diminati anak remaja dan masyarakat umum yaitu video blogging atau vlog [10]. Menurut penelitian Printina menyatakan adanya perbedaan tingkat pengetahuan antara kelompok control dan kelompok intervensi (pvalue 0,000 ) dimana promosi kesehatan dengan video vlog bagi siswa dapat meningkatkan pengetahuan tentang penyalahgunaan narkoba [8].

Penelitian ini bertujuan untuk melihat efektivitas promosi kesehatan menggunakan vlog terhadap tingkat pengetahuan remaja tentang HIV/AIDS di SMK.

\section{METODE}

Penelitian ini menggunakan metode kuantitatif dengan pre-experimental designs one group pretest and postest untuk melihat perbedaan nilai pengetahuan sebelum dan sesudah diberikan promosi kesehatan. Penelitian ini dilakukan disalah satu SMK di Jakarta dari bulan Juni-Juli 2020. Teknik pengambilan sampel menggunakan 
purposive sampling sebanyak 64 sampel. Responden penelitian ini terdiri dari siswasiswi kelas 10 dan 11 yang bersedia menjadi responden dan dapat mengakses google form.

Penelitian ini menggunakan alat ukur kuisioner (google form) dan menggunakan media vlog. Kuisioner penelitian ini terbagi menjadi dua yaitu karakteristik responden yang terdiri dari Jenis kelamin, kelas, dan sumber infromasi yang pernah mendapatkan promosi kesehatan mengenai HIV/AIDS, sedangkan kuisioner pengetahuan terdiri dari 32 pernyataan, 19 pernyataan positif dan 13 pernyataan negatif yang telah dinyatakan valid dan reliable dengan nilai cronbach's alpha 0,949.

Analisis data bivariat untuk melihat perbedaan pengetahuan sebelum dan sesudah diberikan promosi kesehatan dengan menggunakan uji statistik Wilcoxon, sedangkan untuk melihat hubungan antara promosi kesehatan menggunakan vlog terhadap perubahan tingkat pengetahuan menggunakan uji kendall's Tau-C. Penelitian ini telah mendapat persetujuan dari pihak sekolah SMK di Jakarta dan komite Etik STIK Sint Carolus pada bulan Juli 2020 dengan nomer surat 036.A/KEPPKSTIKSC/VII/2020.

Penelitian ini memperhatikan aspek etika penelitian yaitu pertama, peneliti memberikan inform consent kepada responden untuk menyatakan kesediaan. Kedua, peneliti hanya mencantumkan kode dan identitas responden dirahasiakan. Sehingga pada halaman pertama google form berisi mengenai inform consent dan responden dapat melanjutkan dengan klik tanda "Setuju", apabila tidak bersedia maka responden bisa mengklik "Tidak Setuju" dan keluar dari link google form yang diberikan. Untuk memastikan kebenaran data, peneliti membuat grup whatsapp bagi responden dan memandu responden untuk mengisi link kuesioner yang telah diberikan.

\section{HASIL}

Penelitian ini dilakukan di Sekolah Menengah Kejuruan yaitu pada siswa dan siswi perhotelan. Adapun lokasi sekolah ini berdekatan dengan lokasi prostitusi aktif dan siswa dan siswi pada SMK ini baru satu kali mendapat promosi kesehatan mengenai HIV/AIDS dalam bentuk seminar.

Tabel 1

Tingkat Pengetahuan Siswa-siswi SMK Sebelum dan setelah Diberikan Promosi Kesehatan

\begin{tabular}{lccccc}
\hline \multirow{2}{*}{ Indikator } & \multicolumn{2}{c}{ Sebelum } & \multicolumn{2}{c}{ Setelah } & \\
& intervensi & \multicolumn{2}{c}{ intervensi } & \multirow{2}{*}{$\mathrm{p}$} \\
\cline { 2 - 5 } & $\mathrm{f}$ & $\%$ & $\mathrm{f}$ & $\%$ & \\
\hline Pengetahuan & & & & & \\
Baik & 14 & 21.9 & 46 & 71.9 & $0,0001^{*}$ \\
Cukup & 45 & 70.3 & 18 & 28.1 & \\
Kurang & 5 & 7.8 & 0 & 0 & \\
\hline
\end{tabular}

*Wilcoxon test

Tabel 1 menunjukkan bahwa tingkat pengetahuan siswa-siswi Cukup dan baik sebelum dilakukan promosi kesehatan melalui video dan mengalami peningkatan pengetahuan yaitu pada responden yang memiliki pengetahuan baik meningkat dari 14 orang $(21,9 \%)$ menjadi 46 orang $(71,9 \%)$ dan responden yang memiliki pengetahuan kurang mengalami peningkatan pengetahuan setelah diberikan promosi kesehatan melalui media video.

Berdasarkan data kuesioner yang diisi oleh responden menunjukkan bahwa hasil pretest dan post-test paling banyak menjawab benar antara lain pada item tentang "HIV merupakan penyakit menular" kemudian jawaban benar lainnya terdapat pada item tentang "cara penularan HIV/AIDS, cara pencegahan HIV/AIDS". Pengetahuan responden tentang HIV/AIDS pada pre-test berada dalam kategori cukup, sedangkan hasil post-test mengalami peningkatan pengetahuan menjadi kategori baik, dilihat dari pernyataan kuisioner mengenai "HIV merupakan penyakit menular" dari 63 $(98,4 \%)$ menjawab benar pada pre-test menjadi 64 (100\%) menjawab benar pada hasil post-test. Kemudian jawaban benar responden lainnya tentang cara penularan HIV/AIDS juga mengalami kenaikan. 
Berdasarkan data tersebut disimpulkan bahwa pengetahuan siswa-siswi mengalami kenaikan dari kategori cukup menjadi kategori baik.

Hasil analisis menunjukkan bahwa terdapat perbedaan yang bermakna antara pengetahuan sebelum dengan setelah dilakukan intervensi $(\mathrm{p}<0,05)$. Berdasarkan hasil uji statistik diketahui bahwa semua responden yaitu 64 siswa memiliki pengetahuan lebih baik setelah diberikan promosi kesehatan. Sehingga dapat disimpulkan bahwa mayoritas siswa siswi memiliki nilai yang sangat bagus berdasarkan dengan hasil promosi kesehatan melalui vlog serta menunjukkan perubahan tingkat pengetahuan yang baik.

\section{PEMBAHASAN}

Hasil penelitian menunjukkan bahwa terdapat peningkatan pengetahuan setelah dilakukan intervensi. Hal ini sejalan dengan penelitian yang dilakukan oleh Katharina dan Yuliana [11] yang menyatakan bahwa hasil pre-test sebelum penyuluhan dari $65,6 \%$ dengan jumlah 21 orang dikategorikan kurang, hasil post-test setelah penyuluhan pengetahuan meningkat menjadi $84,4 \%$ dengan jumlah 27 orang dikategorikan baik.

Penelitian ini dikuatkan oleh penelitian Angela [12] yang menyatakan bahwa 93.5\% siswa-siswi memiliki tingkat pengetahuan yang tinggi. Hal ini dibuktikan dengan mayoritas responden memahami pengertian, penularan, pencegahan, stigma dan pengobatan HIV/AIDS. Pengetahuan dan sikap remaja yang relatif baik terdapat perilaku pencegahan HIV/AIDS di Indonesia khususnya pada anak sekolah, seharusnya dapat mengurangi angka kejadian HIV/AIDS di Indonsia.

Hal ini sejalan dengan penelitian yang dilakukan oleh Liawati yang menyatakan bahwa setelah penyuluhan pengetahuan responden meningkat [13]. Printina juga menyatakan bahwa $93.5 \%$ siswa-siswi memiliki tingkat pengetahuan yang tinggi [8]. Hal ini dibuktikan dengan mayoritas responden memahami pengertian, penularan, pencegahan, stigma dan pengobatan HIV/AIDS. Pengetahuan dan sikap remaja yang relatif baik terdapat perilaku pencegahan HIV/AIDS di Indonesia khususnya pada anak sekolah, seharusnya dapat mengurangi angka kejadian HIV/AIDS di Indonsia. Penelitian ini didukung juga oleh penelitian Liawati menyatakan bahwa 83\% remaja memiliki tingkat pengetahuan yang baik tentang HIV/AIDS dikarenakan 100\% reponden mengetahui penyebab HIV/AIDS dan responden juga dipengaruhi oleh promosi kesehatan yang mudah didapatkan melalui sumber informasi elektronik [13].

Menurut peneliti, peningkatan pengetahuan responden pada penelitian ini terjadi karena responden sudah terpapar dengan promosi kesehatan yang diberikan sehingga reponden mengerti materi yang diberikan.

Hasil penelitian menunjukkan bahwa ada perbedaan pengetahuan siswa-siswi terkait HIV/AIDS pada hasil pre-test dan post-test setelah dilakukan perlakuan atau diberikan promosi kesehatan. Peningkatan pengetahuan terjadi karena pendidikan kesehatan yang diberikan tersampaikan dengan benar dan tepat. Seperti hasil yang didapatkan peneliti pada siswa-siswi SMK, peningkatan pengetahuan terjadi karena responden telah mendapatkan promosi kesehatan dengan jangka waktu 1 minggu melalui pemutaran vlog HIV/AIDS, sehingga para siswa-siswa yang belum mengerti menjadi lebih paham terkait HIV/AIDS. Hal ini dikuatkan oleh Sondang [14] bahwa remaja dapat memiliki pengetahuan yang baik apabila dilakukan strategi dan pendegahan HIV/AIDS yang sesuai dengan karakteristik remaja itu sendiri.

Hasil ini sejalan dengan penelitian yang dilakukan Handayani oleh menunjukkan nilai signifikasi rata-rata skor pengetahuan sebesar $0,000<0,05$ yang artinya pendidikan kesehatan dengan media video 
berpengaruh dalam meningkatkan pengetahuan remaja tentang HIV/AIDS [15]. Penelitian yang dilakukan oleh Risdiana menyatakan bahwa terdapat perbedaan yang bermakna sebelum dan setelah dilakukan penyuluhan tentang pencegahan HIV/AIDS [16]. Hal ini dikuatkan oleh penelitian yang dilakukan oleh Sovia menyatakan bahwa, didapatkan nilai $p$-value sebesar 0,000 < 0,05 [17]. Hal ini menunjukkan adanya perbedaan pengetahuan remaja sebelum dan sesudah diberikan pendidikan kesehatan tentang HIV/AIDS melalui media Audiovisual. Penelitian yang dilakukan oleh Fadilah menyatakan adanya perbedaan nilai pretest dan post-test setelah dilakukan promosi kesehatan dengan hasil $p$-value sebesar 0,000 peneliti menyatakan bahwa media audiovisual (vlog) efektif digunakan pada anak remaja untuk meningkatkan pengetahuan, dengan adanya gambar vital membuat para remaja lebih tertarik dan memperhatikan materi yang disampaikan [9]. Dari beberapa hasil penelitian tersebut dapat disimpulkan bahwa Peningkatan pengetahuan terjadi karena pendidikan kesehatan yang diberikan informasinya tersampaikan dengan benar dan tepat. Seperti hasil yang didapatkan peneliti pada siswa-siswi SMK Paskita Global, peningkatan pengetahuan terjadi karena responden telah mendapatkan promosi kesehatan dengan jangka waktu 1 minggu melalui pemutaran vlog HIV/AIDS, sehingga para siswa-siswa yang belum mengerti menjadi lebih paham terkait HIV/AIDS [8,16-18].

Media vlog merupakan kegiatan blogging dalam bentuk video, yang dikomunikasikan dalam bentuk verbal yakni secara lisan maupun tulisan dan non-verbal seperti ekspresi wajah, gerakan tangan dan cara berbicara [19]. Penyampaian materi atau promosi kesehatan dengan vlog memiliki kelebihan yakni, dengan adanya gambar dan suara dapat menarik perhatian siswasiswi untuk menonton sehingga promosi kesehatan yang disampaikan lebih mudah dipahami. Selanjutnya vlog dapat diputar dimana saja dan mudah untuk dibagikan ke orang lain. Media perangkat dalam membuat vlog antara lain kamera digital yang bisa merekam video atau menggunakan ponsel, untuk membuat vlog ada 5 tahap yakni menentukam tema sesuai dengan tujuan membuat video, membuat channel youtube, pengambilan video dengan memperhatikan kualitas audio serta pencahayaan, proses Editing video, dan proses publish video.

Pada penelitian ini, media vlog dapat merubah tingkat pengetahuan responden, dilihat dari total 64 responden mengalami perubahan pengetahuan. Dalam melakukan promosi kesehatan terkait HIV/AIDS ada beberapa media yang bisa digunakan selain menggunakan media vlog, hal ini ditunjukan dari penelitian Sovia menunjukkan bahwa ada perbedaan yang signifikan pada pengetahuan HIV/AIDS sebelum dan sesudah promosi kesehatan menggunakan media animasi yaitu $p$-value $0,000<0,05$ [17]. Peneliti berasumsi bahwa media sosial oleh dapat meningkatkan pengetahuan HIV/AIDS pada kalangan remaja.

Jurnal oleh Fitrianda dengan judul Uji Kelayakan Media Audio Visual berupa video klip "Cegah HIV-AIDS" sebagai media promosi kesehatan [20]. Penelitian ini merupakan research and development (R\&D) dengan pendekatan kualitatif, penentuan informasi penelitian ini menggunakan purposive. Hasil penelitian kelayakan video tentang HIV AIDS mendapatkan respon yang baik, video mengandung unsur suara dan gambar, durasi video cukup tidak membosankan sehingga memberikan daya tarik yang besar. Perolehan informasi dari media audio visual kurang lengkap, sehingga perlu ditambahkan informasi terkait HIV AIDS. Setelah penanyangan media audio visual tentang HIV AIDS audiens memiliki keinginan untuk melakukan pencegahan, serta lebih waspada dan hati-hati terkait HIV-AIDS. 


\section{SIMPULAN}

Pada penelitian ini ditemukan bahwa ada perbedaan pengetahuan yang significant sebelum dan sesudah diberikan promosi kesehatan mengenai HIV/AIDS pada siswi SMK. Promosi Kesehatan HIV/AIDS dengan menggunakan Vlog merupakan salah satu cara pencegahan penularan HIV/AIDS di kalangan remaja. Suatu promosi kesehatan dalam mengubah pengetahuan dan perilaku seseorang tidak bisa dilakukan dengan waktu yang singkat melainkan dilakukan secara terus menerus agar menjadi suatu kebiasaan, seperti halnya membaca dan melakukan pemutaran media informasi sehingga tingkat pengetahuan dapat lebih meningkat.

\section{UCAPAN TERIMAKASIH}

Penulis ingin mengucapkan terima kasih kepada semua responden yang telah berpartisipasi dalam penelitian ini.

\section{REFERENSI}

[1] Noviana N. Konsep HIV/AIDS, Seksualitas \& Kesehatan Reproduksi. Jakarta Timur: CV. Trans Info Media; 2016.

[2] Rokom. Hari AIDS Sedunia, Momen STOP Penularan HIV: Saya Berani, Saya Sehat! Indones Kementrian Kesehat Republik 2019.

[3] Utami S. HIV/AIDS dalam Sustainable Development Goals (SDGs): Insiden, Permasalahan, dan Upaya Ketercapaian di Indonesia. Peran Mat Sains, Dan Teknol Dalam Mencapai Tujuan Pembang Berkelanjutan/SDGs 2018:117-37.

[4] Sistem Informasi HIV-AIDS \& IMS (SIHA). Laporan Perkembangan HIV-AIDS \& Infeksi Seksual Menular (IMS). Narrat Ther Lives 2018:231. https://doi.org/10.1055/s-20081040325.

[5] Agregasi Sindonews.com. Ratusan Remaja di Bekasi Menghidap HIV/AIDS Karena Seks Bebas. OkezoneCom 2019.

[6] Berek PAL. Relationship Between Gender and Age With Adolescent Levels of Knowledge About HIV / AIDS at SMAN 3 Atambua, East Nusa Tenggara 2018 MARIA FLORIDA BE 2) YUSFINA MODESTA RUA 3) CHRISTINA ANUGRAHINI 4) 2018:1-13.
[7] RI KK. Rencana Aksi Nasional Pengendalian HIV-AIDS 2015-2019 2015.

[8] Printina AB. Pengaruh Promosi Kesehatan Melalui Video Vlog Terhadap Tingkat Pengetahuan Tentang Penyalahgunaan Narkoba Pada Siswa Siswi Di Smp Strada Marga Mulia Jakarta Selatan. J Ris Kesehat Nas 2018;2:59. https://doi.org/10.37294/jrkn.v2i1.89.

[9] Fadilah M, Syakurah AR, Fikri MZ. Perbandingan promosi kesehatan melalui media audiovisual dan metode ceramah terhadap tingkat pengetahuan anak SD mengenai penyakit TB Paru. Fakt Risiko Pedikulosis Kapitis Di Panti Asuhan Laras 2019.

[10] Larasati AT, Manalu SR. Dampak Menonton Vlog terhadap Perilaku Viewers Remaja (Studi Eksploratif Penonton Vlog). Interak Online 2017;5:1-11.

[11] Katharina T, Yuliana Y. Pengaruh Penyuluhan Kesehatan Reproduksi melalui Audio Visual dengan Hasil Pengetahuan Setelah Penyuluhan pada Remaja SMA Negeri 2 Pontianak Tahun .... J Kebidanan 2018;7:4754.

[12] Angela M, Sianturi SR, Supardi S. Hubungan antara Pengetahuan, Sikap dan Perilaku Pencegahan HIV/AIDS pada Siswa SMPN 251 Jakarta. J Penelit Dan Pengemb Pelayanan Kesehat 2019;3:67-72.

[13] Abstrak L, Belakang L, Virus HI, Immune A, Syndrome D, Hiv P, et al. Perbedaan Tingkat Pengetahuan Siswa Sebelum Dan Sesudah Diberikan Penyuluhan Pencegahan Hiv / Aids 2019;9:32-41.

[14] Sianturi SR. Prevention Strategies for HIV in Youth: A Concept Analysis. Nurse Media J Nurs 2015;5:15. https://doi.org/10.14710/nmjn.v5i1.10187.

[15] Handayani L. Video Terhadap Tingkat Pengetahuan Tentang Pencegahan Hiv / Aids Di Sma Negeri 1 Parigi Kabupaten Pangandaran Video Terhadap Tingkat Pengetahuan Tentang Pencegahan Hiv / Aids Di Sma Negeri 1 Parigi Kabupaten. Naskah Publ 2017.

[16] Risdiana I. Perbedaan Pengetahuan Remaja Tentang HIV/AIDS Sebelum Dan Sesudah Diberikan Pendidikan Kesehatan Menggunakan Media Audiovisual Di SMPN 2 Bandungan 2019.

[17] Sovia S, Suharti S, Daryono D. Efektifitas Penggunaan Media Animasi Untuk Meningkatkan Pengetahuan Tentang Hiv/Aids. Jambura J Heal Sci Res 2019;1:37- 
46.

https://doi.org/10.35971/jjhsr.v1i2.2398.

[18] Liawati. Perbedaan Tingkat Pengetahuan Siswa Sebelum dan Sesudah Diberikan Penyuluhan Penvegahan HIV/AIDS 2019;9:32-41.

[19] Prasetyo CB, Kusumawati A. Pengaruh Vlog Sebagai Electronic Word Of Mouth Terhadap Minat Beli dan Dampaknya Terhada Keputusan Pembelian (Survei kepada
Konsumen yang Menonton Video YouTube Channel \&quot;Faris Malang \& quot; pada Kuliner Malang). J Adm Bisnis (JAB)|Vol 2018;62:118-26.

[20] Fitrianda MI. Digital Digital Repository Repository Universitas Universitas Jember Jember Digital Digital Repository Repository Universitas Universitas Jember 2013. 